\title{
110 野球投手が投じる様々な球種の飛翔軌道を決定する要因
}

Factors to determine the flight trajectory in various kinds of baseball pitch.

○永見 智行（早稲田大学）

矢内 利政 (早稲田大学)
桶口 贵俊 (早稲田大学)
彼末 一之 (早稲田大学)

Tomoyuki NAGAMI, Waseda University, 2-579-15 Mikajima, Tokorozawa-shi, Saitama

Takatoshi HIGUCHI, Waseda University

Toshimasa YANAI, Waseda University

Kazuyuki KANOSUE, Waseda University

The purpose of this study was to investigate the relationship between the flight trajectory of the ball and ball spin in various kinds of baseball pitch. Each subject thrown various kinds of their own pitches for three throws each. The pitched balls were recorded using 4 high-speed video cameras. The flight trajectory, ball spin rate, and direction of spin axis were obtained from the video images, and hypothetical flight trajectory with free fall was calculated from ball initial velocity. Equations were obtained to estimate the displacement of the flight trajectory from that of the free fall ball using "decomposed spin parameter" which consists of the ball spin rate, direction of spin axis, and initial velocity $(p<0.001)$. The findings showed that the displacement of the flight trajectory depended on the ball spin rate and direction of spin axis, thereby accurately predictable from the spin. The characteristics of ball spin can be utilized to develop a strategy to alter the flight trajectory.

Key Words: - ball spin, 3d videography, fastball, slider >

\section{1. 锋者}

野球の投手は直球や様々な変化球を投げ分け，打者を打ち 取ろうとする.こういった投球の種類（球種）の差異は，ボ 一ルの飛翔軌道の差異で表される. ボールの飛翔軌道を決定 する要因として, リリース直後の1) ボール移動速度，2）ボ 一ル回転速度，3）ボール回転軸の向き，4）回転軸に対する ボール維目の向きが挙げられ (Nathan $\left.{ }^{1}\right)$ ，特に投手はボール の回転を調節し, 飛翔するボールの変位の大きさやその方向 を変化させようとする.しかし回転をどのように変化させれ ば理想的な飛翔軌道が実現するのかが分からず，うまく投球 できないことも多い，

ボールの回転が飛翔軌道に与える影響を検討した研究に は，風洞内でボールを回転させ，その空力特性を計測したも のが多い。これらの寒験からは，ボールの回転軸が谁行方向 と直交するとき，発生する揚力の大きさはスピンパラメータ ( $\mathrm{Sp}$, 回転速度と移動速度の比. 後述) の大きさに依存する ことが明らかとなっている（Briggs², Watts and Ferrer ${ }^{3}$, Alaways and Hubbard ${ }^{4}$, Nathan $^{1}$ )。一方でボールの回転軸が進 行方向を向く場合は, 揚力が発生しないことが分かっており

(溝田ら ${ }^{5}$ ), 必ずしも揚力はスピンパラメータに依存するわ けではない. また, 回転軸に対するボールの縫目の向きの違 いが発生する揚力に影晦を与えるとする報告 (Alaways and Hubbard ${ }^{4}$, 溝田ら ${ }^{5}$ ) もあるが, 影響は無いとする研究（高 見ら $\left.{ }^{6}\right)$ もあり，見解は一致していない。

一方実際に投手が投じたボールの回転を詳細に分析した 研究では, 直球やカーブ (Jinji et al. ${ }^{7}$, Nagami et al. ${ }^{8}$ ) に関す るものがあり，投手によって，また球種によって回転軸の向 きや回転速度が異なることが分かっている.しかし様々に異 なる回転軸の向きや回転速度の違いが, 飛翔軌道にどの程度 の影鳘を与えているかは不明である，以上のことから，そも そも投手が投球することが可能な変化球や，理想とする飛翔 軌道を実現するために必要なボールの回転を把握すること は，投手の指導や練習に役立つと考えられる。

本研究では, 実察に投手が投じる様々な球種のボール回転 （回転速度, 回転軸角度, 縫目の向き）と飛翔軌道の関係を 明らかにする. その際，指導や実践の現場への応用を念頭に， ボールに濑くカそのものではなく，どれだけ曲がるか，落ち るかといったボールの変位量に着目する．またボールの回転 はサイドスピン成分とトップ/バックスピン成分に分解し，
水平、垂直方向への変位量との関係を明らかにする.

\section{2. 方法}

\section{2-1 被検者}

被験者は大学野球部投手 7 名とした．被験者の身長は 1.80 $\pm 0.04 \mathrm{~m}$, 体重は 74.6 $44.1 \mathrm{~kg}$ であり，全員右投げであった。 被験者には文章及び口頭で実験内容を十分に説明し，実験参 加の同意を得た. なお本研究は早稲田大学の「人を対象とす る研究に関する倫理委員会」の承認を得て行われた.

\section{2-2 实飡手順}

被験者には十分なウォーミングアップを行わせた後，実験 用に設置された正規規格の投球マウンドから捕手に向けて， 直球とその他投球可能な変化球を 3 球ずつ投球させた.

この際，リリースから捕手が捕球するまでのボールの飛翔 する様子を 3 台の同期された高速度ビデオカメラ（Fig. 1 内

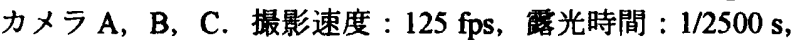
ピクセル数：1280×1024, Fastec Imaging 社製) で撮影した. また, リリース直後約 $100 \mathrm{~ms}$ 間でボールが回転する様子を, 投球マウンド後方（2 畋側）に設置した高速度ビデオカメラ

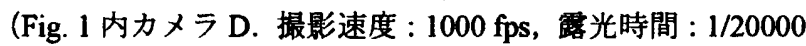
s, ピクセル数 : $640 \times 480$, Fastec Imaging 社製) で撮影した。 投球終了後，映像の較正点として，放射状に 68 点のマーカ 一が配置された較正器（直径 $2.4 \mathrm{~m}$, 較正点間隔 : $0.50 \mathrm{~m}$ ) を 5 箇所に設置し，カメラ A, B , C で撮影した。

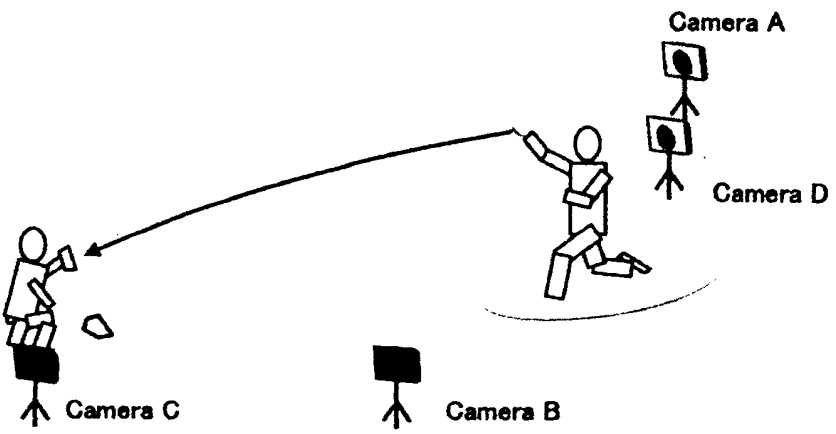

Fig. 1 Cameras setting. 

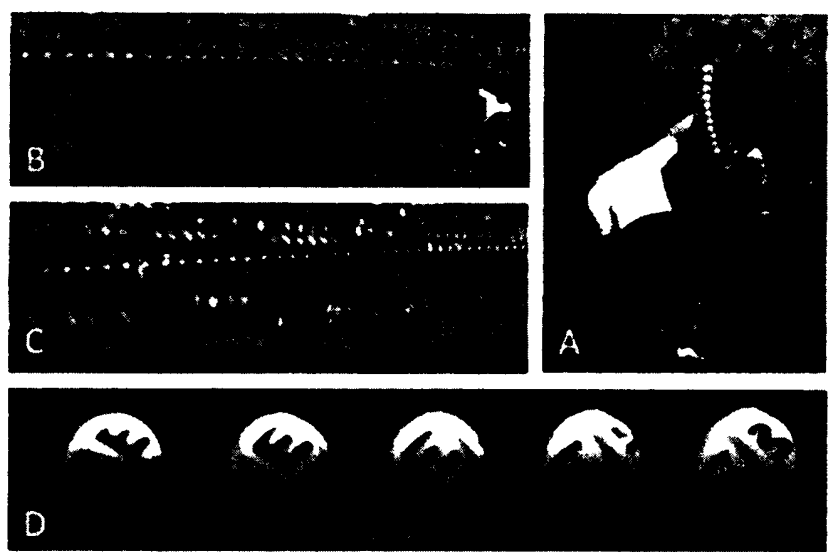

Fig. 2 Recorded images

\section{2-3 データ処理}

\section{2-3-1 ボール我翔轨道の解析}

カメラ A, B, C の映像から, 解析ソフト (Frame-Dias 4, DKH 社製) を用い, 3D-DLT 法 (Abdel-Aziz et al. ${ }^{9}$ ) によっ てボール中心の 3 次元座標值を算出した. 空間座標系はピッ チャープレートの長軸中央, 捕手寄りの点の直下で, ホーム ベースの置かれた水平面上を原点とした空間座標系（投球方 向を $\mathrm{Y}$ 軸（捕手に向かって正），左右方向を $\mathrm{X}$ 軸（3 畕に向 かって正), 垂直方向を Z 軸 (上方に向かって正))とした (Fig. 3). 座標值の各成分はバターワース型のローパスデジタルフ イルタで平滑化した，遮断周波数 $(6 \sim 8 \mathrm{~Hz})$ は残差分析法 $\left(W_{\text {Winter }}{ }^{10}\right)$ を用いて決定した. リリース直後とその 2 コマ 後 (16 ms 後) のボール中心座標から, 移動速度 (v) とX-Y 平面 ( $\mathrm{Y}$ 軸方向を $0^{\circ}$ とし， 3 祵方向が正)，Z-Y 平面 (水平 方向を $0^{\circ}$ とし, 上方向が正)における投射角度を算出した. この初期条件から, 自由落下すると仮定した飛翔軌道を算出 し, ホームベースの頂点 $(\mathrm{Y}=18.44[\mathrm{~m}])$ を通る X-Z 平面を 通過する際の座標值（自由落下捕球位圈）を算出した。 また 実際にこの面を通過する際の座標値（実際の捕球位置）を， 捕球直前 10 コマの座標值を最小二乗法により算出された二 次近似式から算出した. 実際の捕球位置と自由落下捕球位置 との水平成分, 垂直成分の差をボールの変位量 $(\Delta \mathrm{X}, \Delta \mathrm{Z})$ とした (Fig. 3).

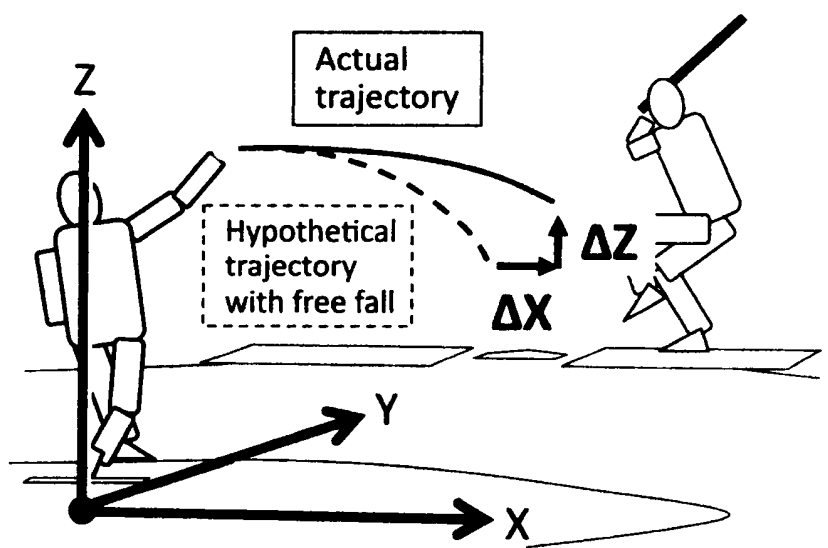

Fig. 3 Global coordinate system and the definition of the $\Delta X$ and $\Delta Z$.

\section{2-3-2 ボール回枟の羁析}

カメラ Dの映像から, ボール中心を原点とし, 映像横方向 を $\mathrm{X}_{\mathrm{B}}$ 軸, 垂直方向を $\mathrm{Z}_{\mathrm{B}}$ 軸, 奥行き方向を $\mathrm{Y}_{\mathrm{B}}$ 軸とするボー ル座標系を設定した. カメラレンズの光軸を空間座標系の $\mathrm{Y}$ 軸と概ね一致しているため, ボール座標系の各軸は空間座標
系の各軸と平行であると考える。この映像から特製の測定器 を用い，ボールの回転速度（revolutions per second, rps), 回 転軸角度（方位角 $\theta$ （進行方向（ $Y_{\mathrm{B}}$ 軸正方向）が正), 仰俯 角 $\phi$ (上方向 $\left(Z_{B}\right.$ 軸正方向 $)$ が正, Fig. 4) ) を算出した (Nagami et al. $\left.{ }^{8}\right)$. 回転軸の向きは右ねじの方向とした。また同じ映像 から目視により,ボールの回転を 4 シーム回転, 2 シーム回 転, それら以外に分類した。

\section{2-3-3 回枟粙角度及びスピンパラメータの分解}

計測されたボール移動速度，回転速度から，以下の式によ りスピンパラメータ（Sp）を算出した。

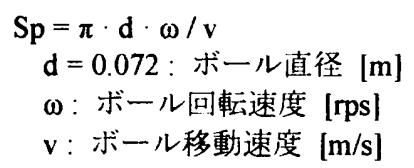

また，回転軸を $Z_{\mathrm{B}}$ 軸成分， $\mathrm{X}_{\mathrm{B}}$ 軸成分に分解し，スピンパ ラメー夕の水将方向成分 $\left(\mathrm{Sp}_{\mathrm{hor}}\right)$, 垂直方向成分 $\left(\mathrm{Sp}_{\mathrm{ver}}\right)$ を 算出した（Fig. 4).

$$
\begin{aligned}
& S p_{\text {hor }}=S p \cdot \sin \varphi . \\
& S p_{\text {ver }}=S p \cdot \cos \theta \cdot \cos \varphi .
\end{aligned}
$$

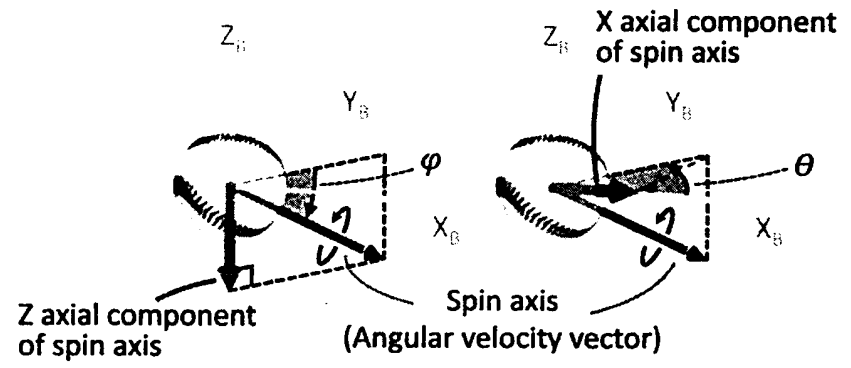

Fig. 4 Definition of the azimuth $(\theta)$ and elevation $(\varphi)$ angle for calculating the $\mathrm{Sp}_{\text {hor }}$ and the $\mathrm{Sp}$ ver.

\section{2-3-4 統部迈理}

全投球における $\mathrm{Sp}_{\text {hor }}$ と $\Delta \mathrm{X}, \mathrm{Sp}_{\text {ver }}$ と $\Delta \mathrm{Z}$ について，最小二 乗法により直線回㷌分析を行った. 同様に 4 シーム回転の全 投球, 2 シーム回転の全投球における $\mathrm{Sp}_{\text {hor }}$ と $\Delta \mathrm{X}, \mathrm{Sp}$ ver と $\Delta Z$ についてもそれぞれ直線回㷌分析を行い，それぞれの回㷌俰 数（傾き， $\mathrm{y}$ 切片）を比較した。 また 4 シームの直球と 2 シ 一ムの直球の双方を投げていた被酫者（6名）の結果から， それらの移動速度, 回転速度, 回転軸角度 (方位角, 仰俯角) $\mathrm{Sp}, \mathrm{Sp}_{\text {hor }}, \mathrm{Sp}_{\text {ver, }} \Delta \mathrm{X}, \Delta \mathrm{Z}$ を, 対応のある $\mathrm{t}$ 検定を用いて比較し た. 各処理には統計ソフト（SPSS ver. 20, IBM 社製）を用 いた.

\section{3. 結果}

Table.1 には, 球種毎の縫目の向き, 平均移動速度, 投射角 度, 変位量 $(\Delta \mathrm{X}, \Delta \mathrm{Z})$, 回転速度, 回転軸角度（方位角 $\theta$, 仰俯角 $\phi), \mathrm{Sp}, \mathrm{Sp}$ hor, $\mathrm{Sp} \mathrm{p}_{\text {ver }}$ 示した. Figure 5 にはボール 座標系における X-Z 平面, $\mathrm{X}-\mathrm{Y}$ 平面における回転軸の向きを 球種毎に示した. 図中の1つの回転軸は, 一人の被験者の投 じた同一球種 3 球を平均したものであり, 矢印の先端部は代 表的なものにのみ付加した. Figure 6 には, 投手Aの投じた 5 つの球種の X-Y 平面, $Z$ - $Y$ 平面に投影した飛翔軌道 (実線) と，自由落下したと仮定した際の放物線（点線）を示した. 4 シーム直球と 2 シーム直球については， $\Delta \mathrm{X}$ 及び方位角に のみ，それぞれ有意差（ $\mathrm{AX}: \mathrm{p}<0.01$, 方位角 $: \mathrm{p}<0.05)$ が 認められ，2 シーム直球のほうが右打者方向へと変位してい た. 7 名の被験者が投じた全 75 球において, $\Delta \mathrm{X}$ は $\mathrm{Sp}_{\text {hor }}$ を, $1 Z$ は $\mathrm{Sp}$ ver 孝それぞれ独立変数とした回㷌式で表された 
Table. 1 Ball characteristics of each kind of pitches.

\begin{tabular}{|c|c|c|c|c|c|c|c|c|c|c|c|c|c|c|c|c|c|c|c|c|c|c|c|c|c|c|c|c|}
\hline & \multirow{3}{*}{$\mathbf{n}$} & \multicolumn{3}{|c|}{ Seam orientation } & \multicolumn{4}{|c|}{ Ball speed } & \multicolumn{4}{|c|}{ Projection angle } & \multicolumn{4}{|c|}{ Amount of displacoment } & \multirow{2}{*}{\multicolumn{2}{|c|}{$\begin{array}{l}\text { Spin rate } \\
\text { (rps) }\end{array}$}} & \multicolumn{4}{|c|}{ Direction of spin axis } & \multicolumn{6}{|c|}{ Spin perameler } \\
\hline & & \multirow{2}{*}{$\begin{array}{c}4- \\
\text { seam }\end{array}$} & \multirow{2}{*}{$\begin{array}{l}2- \\
\text { seam }\end{array}$} & \multirow[t]{2}{*}{$?$} & \multicolumn{2}{|c|}{$\begin{array}{l}\text { Initial } \\
(\mathrm{m} / \mathrm{s})\end{array}$} & \multicolumn{2}{|c|}{$\begin{array}{l}\text { Final } \\
(\mathrm{m} / \mathrm{s})\end{array}$} & \multicolumn{2}{|c|}{$\begin{array}{l}\text { Horizontal } \\
\text { (deg) }\end{array}$} & \multicolumn{2}{|c|}{$\begin{array}{l}\text { Vertical } \\
\text { (deg) }\end{array}$} & \multicolumn{2}{|c|}{$\underset{(\mathrm{mm})}{\mathrm{U}}$} & \multicolumn{2}{|c|}{$\begin{array}{c}N Z \\
(\mathrm{~mm})\end{array}$} & & & \multicolumn{2}{|c|}{$\begin{array}{c}\theta \\
(\operatorname{deg})\end{array}$} & \multicolumn{2}{|c|}{$\begin{array}{c}\Phi \\
(\operatorname{deg})\end{array}$} & \multicolumn{2}{|c|}{ Sp } & \multicolumn{2}{|c|}{$S p$ hor } & \multicolumn{2}{|c|}{$S p_{\text {ver }}$} \\
\hline & & & & & Ave & SD & Ave & SD & Ave & SD & Ave & SD & Ave & SD & Ave & SD & Ave & So & Ave & SD & Ave & SD & Ave & SD & Ave & SD & Ave & SD \\
\hline $4-\operatorname{seam} F B$ & 7 & 7 & - & - & 35.5 & 3.0 & 32.3 & 2.5 & -4.1 & 0.6 & 0.0 & 2.0 & 272 & 82 & 362 & 120 & 32.8 & 4.5 & 23 & 25 & -31 & 8 & 0.209 & 0.016 & -0.106 & 0.024 & 0.149 & 0.040 \\
\hline 2-seem FB & 6 & $\cdot$ & 6 & - & 32.8 & 2.7 & 29.9 & 2.4 & -2.7 & 1.3 & 0.9 & 1.0 & 348 & 84 & 261 & 73 & 27.6 & 4.2 & 20 & 33 & -41 & 12 & 0.190 & 0.021 & -0.123 & 0.034 & 0.109 & 0.024 \\
\hline Slider & 6 & 1 & 3 & 2 & 31.1 & 2.5 & 28.5 & 2.1 & -2.8 & 0.8 & 1.3 & 1.2 & -149 & 70 & 6 & 72 & 35.9 & 5.2 & 96 & 12 & 19 & 9 & 0.261 & 0.029 & 0.084 & 0.042 & -0.028 & 0.052 \\
\hline Forkball & 3 & - & 3 & - & 32.8 & 2.2 & 30.4 & 2.3 & -3.3 & 0.4 & -0.8 & 1.8 & 188 & 74 & -39 & 63 & 14.9 & 5.7 & 80 & 25 & -24 & 15 & 0.101 & 0.034 & -0.043 & 0.035 & 0.020 & 0.035 \\
\hline Curveball & 1 & 1 & - & - & 31.1 & - & 28.5 & $\cdot$ & -1.8 & - & 2.1 & - & -200 & - & -257 & - & 37.6 & - & 129 & - & 23 & - & 0.273 & - & 0.107 & - & -0.158 & - \\
\hline Cut FB & 1 & 1 & - & - & 34.8 & - & 32.7 & - & -3.0 & - & -1.7 & - & -98 & - & 68 & - & 41.9 & - & 84 & - & 7 & - & 0.272 & - & 0.031 & - & 0.026 & - \\
\hline Change-up & 1 & 1 & - & - & 30.6 & - & 28.5 & - & -3.4 & - & -0.7 & - & 280 & - & 220 & - & 16.5 & - & 27 & - & -40 & - & 0.122 & - & -0.079 & - & 0.083 & - \\
\hline
\end{tabular}
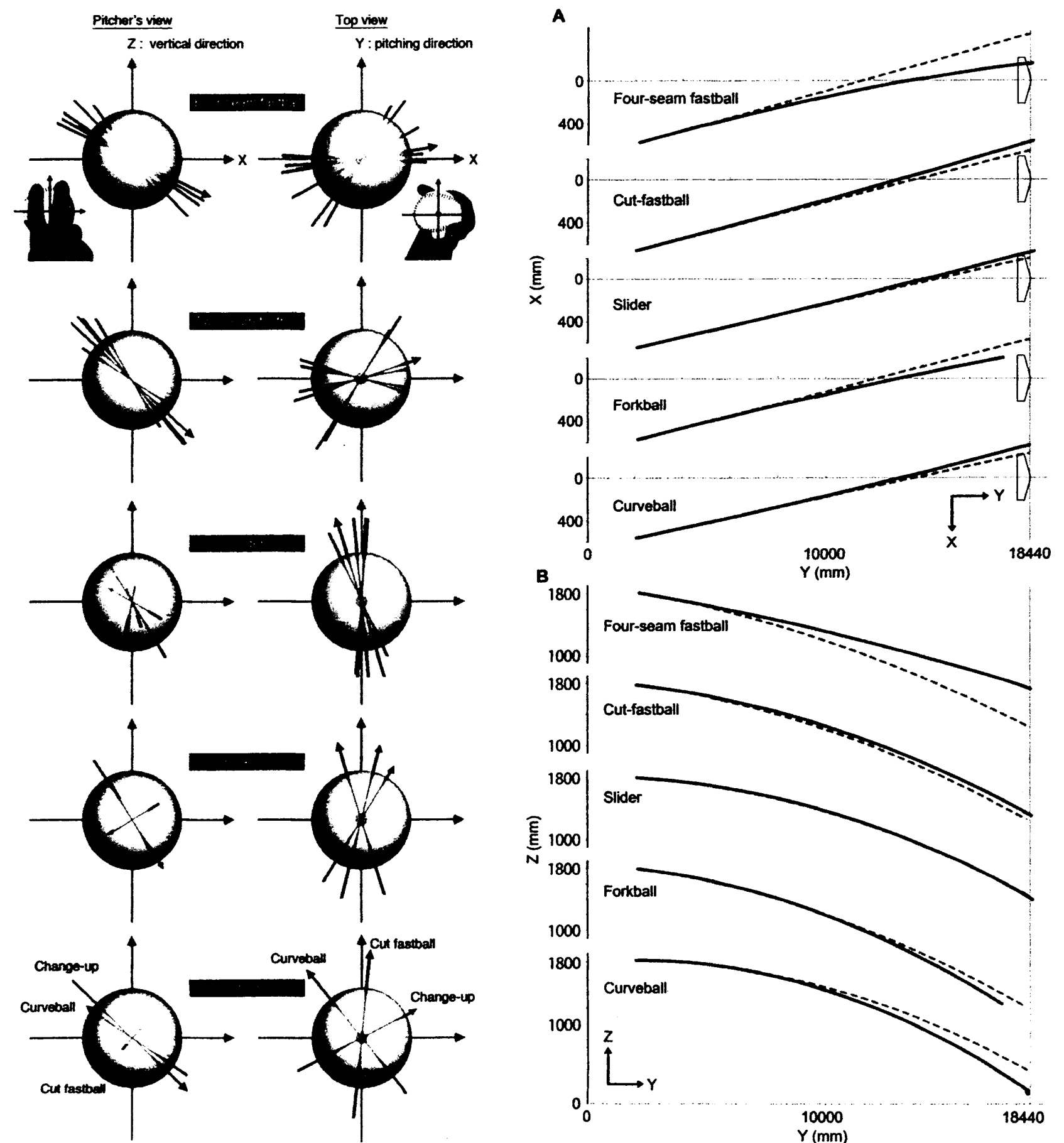

Fig. 5 Direction of spin axes of the seven kinds of pitches.

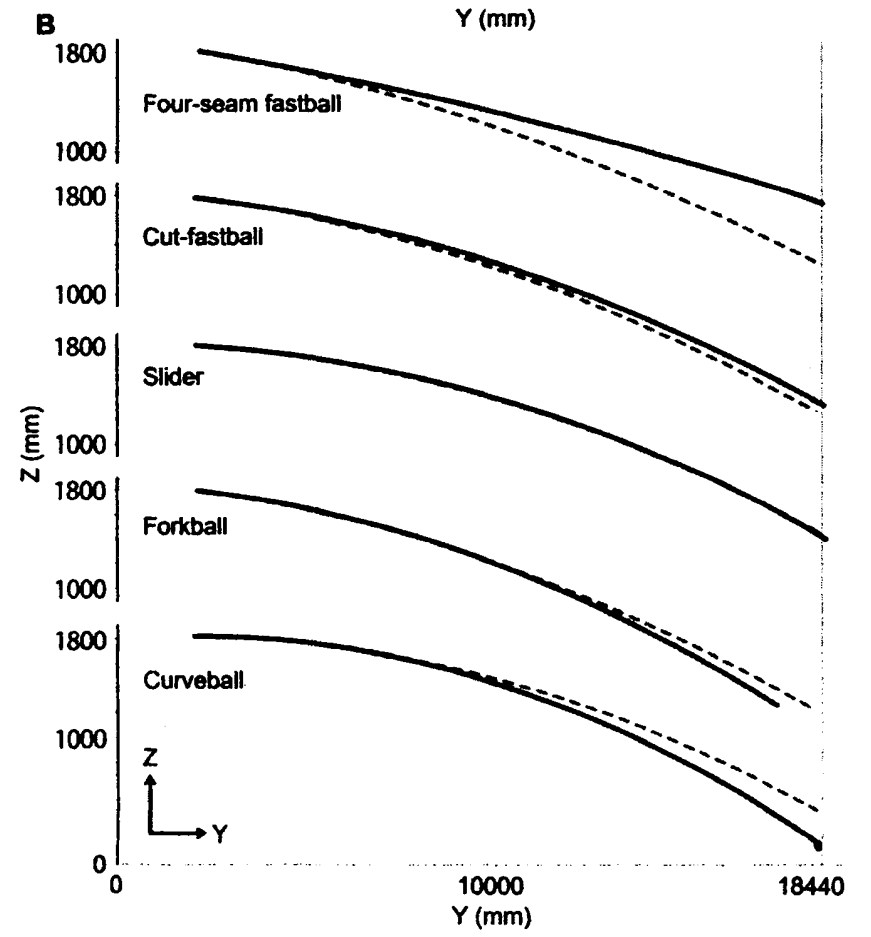

Fig. 6 Flight trajectories of the balls thrown by Sub. A. 

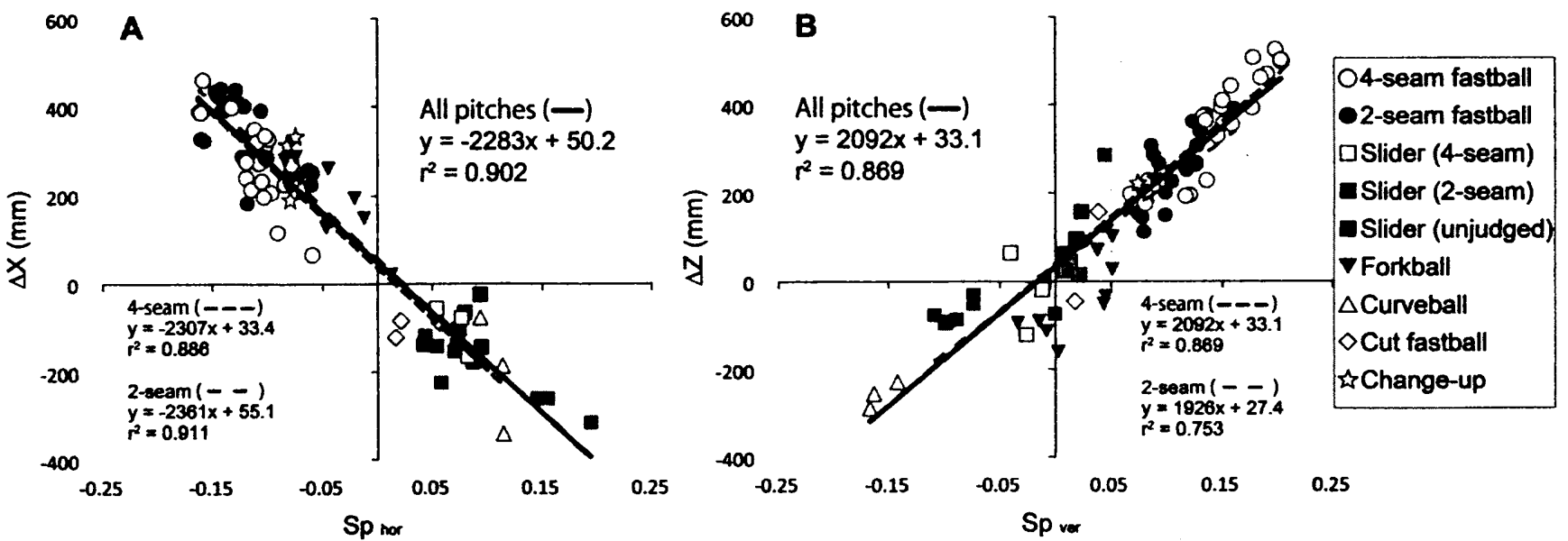

Fig. 7 Relationship between $\mathrm{A}) \mathrm{Sp}_{\text {hor }}$ and $\Delta \mathrm{X}$, and B) $\mathrm{Sp}_{\text {ver }}$ and $\Delta \mathrm{Z}$. Open marks are pitches with four-seam spin, black closed marks are pitches with two-seam spin, and gray closed marks are pitches which spins were unjudged whether four- or two-seam.

$\left(\Delta \mathrm{X}: \mathrm{R}^{2}=0.902, \mathrm{p}<0.001, \Delta \mathrm{Z}: \mathrm{R}^{2}=0.869, \mathrm{p}<0.001\right.$, Fig. 7). 一方で, 4 シーム回転の球種のみでの回帰係数（傾き，切片） と 2 シーム回転の球種のみでの回帰係数との間に差は認めら れなかった.

\section{4. 考察}

\section{4-1 交位年を決定する夏因}

投球の左右，上下方向への変位量 $(\Delta \mathrm{X}, \Delta \mathrm{Z})$ は，サイド スピン成分とトップ/バックスピン成分に分解したスピン パラメータ $\left(\mathrm{Sp}_{\text {hor, }}, \mathrm{Sp}_{\text {ver }}\right)$ によってそれぞれ $90 \%, 87 \%$ 説明 できることが分かった.このことから，本研究における回転 軸方向の分解とこれを用いたスピンパラメータの分解法が， 変位量の算出に有効であると言える.

また変位量とスピンパラメータ分解成分の関係において, 繾目の向きの違い (4 シーム, 2 シーム) による回㷌係数の 違いは認められなかった.このことから繾目の向きの違いそ のものがボールに做く揚力に与える影稫は小さいものと考 えられる. 一方で 4 シーム直球と 2 シーム直球では左右方向 への変位量に群間差が認められたが,これは仰侑角の大きさ の違いによって生じたものであると考えられ，繾目に対する 指の掛け方の違いが投じられたボールの回転軸の向きに影 慗を与えたものと推察できる.

\section{4-2 盲球の“伸ひ”}

4 シ一ム直球は最も基本となる球種であり, その評価は移 動速度の速さだけでなく, “伸び”の良し悪しによって表現 される. 本研究の被験者の中では，特に被䤅者 $\mathrm{A}$ の 4 シーム 直球が“伸び”が良いと評価される投球である．実際，被倹 者 A 4 シーム直球の $\Delta \mathrm{Z}$ は $498 \mathrm{~mm}$ で被験者中最大であっ た。これは，一流プロ野球投手，大学野球投手計 22 名の 4 シ一ム直球の移動速度, 回転速度, 回転軸角度 (Nagami et al. 8) を回帰式に代入して得られた $\Delta \mathrm{Z}$ (平均 $365 \pm 61 \mathrm{~mm}$, 最大 $486 \mathrm{~mm}$ ) と比べても大きい．以上のことから，直球の“伸 び”は垂直上方向への変位量の大小によって決定されると考 えられ, 回転速度を高め, かつ仰俯角, 方位角を $0^{\circ}$ に近つ けることでより良い“伸び”獾得することができると考え られる.

\section{4-3 スライダーの “曲がり”}

一般に右投げ投手の投じるスライダーは左打者方向へと 変位する，“鋭く大きく曲がる”投球と考えられている。 し かし本研究で投じられたスライダーは, 回転軸が概ね進行方 向を向いているため $\mathrm{Sp}_{\text {hor }}, \mathrm{Sp}_{\text {ver }}$ がともにほぼぜロであり, $\Delta \mathrm{X}$ は平均-149 $\pm 70 \mathrm{~mm}$ で, 最も大きく左打者方向一変位した投
球でも-313 mm であった，先行研究（永見ら ${ }^{11}$ ) におけるプ 口野球投手の投じるスライダーの回転速度, 回転軸角度も本 研究と同様の傾向であり，一流投手の投じるスライダーでも 同程度の変位量であると言える。，一方で，一般的に左右方向 への変位がほとんど生じないと考えられている4シーム直球 は，スライダーとは反対方向（右打者方向）へ変位していた 上, その変位量 (平均 $272 \pm 82 \mathrm{~mm}$ ) はスライダーよりも大 きい傾向にあった４シーム直球を“まっすぐに向かってく る”ように感じている打者にとって，スライダーが実際より も大きく左打者方向一変位をしているように感じられ，スラ イダーを“鋭く大きく曲がる”投球であると錯覚している可 能性が示唆された。

ただし, 仮に空間座標系での回転軸の向きが飛翔中に変化 していないとしても, 重力に従って落下していくことで進行 方向がより下向きとなれば, 進行方向に対する回転軸の相対 的な向きが変わり，サイドスピン成分が発生すると推察でき る. 実際, 捕球直前のスライダーは約 $10^{\circ}$ 下向きに進んでい たことから, 左打者方向へと変位している可能性も考えられ る. また長谷川ら ${ }^{12}$ は, サイドスピン以外の成分, すなわち 方位角の違いによってボールに横向きの揚力が働くことを 明らかにしており，こういった要因が少なからず影警してい ることも否定できない.

\section{4-4 交位贯を改書するための方策}

得られた回帰式より，投球の左右方向一の変位量を大きく するには，仰俯角を $\pm 90^{\circ}$ に近づけ，回転速度を高めること が有効であると言える.また垂直上方向への変位量を大きく するには, 仰俯角, 方位角を $0^{\circ}$ に, 下方向への変位量を大 きくするためには仰俯角を $0^{\circ}$ ，方位角を $180^{\circ}$ に近つけけ, 回転速度を高めることが有効であると言える.またこういっ た回転の変更によって変わる変位量の大きさも推定できる ようになった。

例えぼ, 被験者 A の投じるスライダーを $72 \mathrm{~mm}$ (ボール直 径分) 大きく落ちるような軌道に改善するためには，方位角 を $95^{\circ}$ から $102^{\circ}$ 人変更することが必要となる. また被験者 $\mathrm{G}$ のスライダーでは, 仰俯角を $20^{\circ}$ から $28^{\circ}$ へ変更するこ とで, 左方向への変位を $72 \mathrm{~mm}$ 増加させられることが分か る.

また被験者 D，Eが投じる 4 シーム直球はどちらも同程度 の $\Delta Z$ であったが, これをボール直径分増加させるには異な る方策が有効であると考えられる. 被験者 D の場合, 仰俯角 が平均よりも大きく下向きに傾いており、これを $-45^{\circ}$ から $-30^{\circ}$ 一変更することで $\Delta \mathrm{Z}$ は $72 \mathrm{~mm}$ 大きくなる. 被験者 D が回転速度の改善によって同じ効果を得ようとすると，45 
rps まで増加させなければならず，現実的ではない，一方の 被㑒者 $\mathrm{E}$ は回転速度を $29.4 \mathrm{rps}$ から $36.0 \mathrm{rps}$ まで増加させれ ば同程度の $\Delta \mathrm{Z}$ が得られる. 一方で, 仮に $0^{\circ}$ まで仰俯角を変 更できたとしても同じだけの効果は得られない.このように, 飛翔軌道を改善しようとする祭は個人々々の回転の特街を 考虑する必要があることが示唆された.

\section{5. まとめ}

本研究では，実除に投手が投じる様々な変化球について， ボールの回転が飛翔軌道に与える影警を検討した, その結果, 桻目の向きに関わらず, サイドスピン成分及びトップ/バッ クスピン成分に分解したスピンパラメータによって, 捕手捕 球位置までの変位量を説明できることが分かった.これによ り, 個々が理想とする変位量を実現するために必要なボール 回檕を知ることができ，個々の特性に合わせた回転の目標値 を設定できるようになった.

\section{考文成}

1) Nathan AM. The effect of spin on the flight of a baseball. Am J Phys. 2008;76(2):119-124.

2) Briggs LJ. Effect of spin and speed on the lateral deflection (curve) of a baseball; and the Magnus effect for smooth spheres. Am J Phys. 1959;27(8):589-596.

3) Watts RG, Ferrer R. The lateral force on a spinning sphere: Aerodynamics of a curveball. Am J Phys. 1987;55:40-4.

4) Alaways LW, Hubbard M. Experimental determination of baseball spin and lift. $J$ Sport Sci. 2001;19(5):349-358.

5) 溝田武人，錦織大介，小西和明. 硬式野球ボールの縦ス ライダに関する流体力測定と飛しょう軌道解析. 日本機 械学会論文集 (B 編). 2007;73(734):1987-1992.

6) 高見圭太, 宮菩武, 姫野龍太郎. バックスピンする球体 に倠く負のマグナスカ〜飛翔実験による測定〜．ながれ． 2009;28:347-356.

7) Jinji T, Sakurai S. Direction of spin axis and spin rate of the pitched baseball. Sports Biomech. 2006;5(2):197-214.

8) Nagami T, Morohoshi J, Higuchi T, Nakata $H$, Naito $S$, Kanosue $K$. The spin on fastballs thrown by elite baseball pitchers. Med Sci Sport Exer. 201 1;43(12):2321-2327.

9) Abdel-Aziz YI, Karara HM. Direct linear transformation from comparator coordinates into object space coordinates in close-range photogrammetry. ASP Symposium on Close Range Photogrammetry. American Society of Photogrammetry, Falls Church, VA. 1971;1-19.

10) Winter DA. Biomechanics and motor control of human movement, John Wiley and Sons. 1990: 41-43.

11) 永見智行, 矢内利政, 彼末一之. 野球投手が投じる変化 球の回転の特徽. 第 22 回日本バイオメカニクス学会大 会発表. O2-B04.

12）長谷川淳哉, 坂本誠馬, 田多輝洋, 鸣尾丈司, 满田武人. 風洞実跧による硬式野球ボールの空力特性（回転軸の方 向の違い). スポーツ・アンド・ヒューマン・ダイナミ クスシンポジウム 2011 講演論文集. Nol1-17:31-34. 